$\begin{array}{rr}\text { FIT(PPATOLOGI } & \text { Volume } 9 \text {, Nomor 5, Oktober } 2013 \\ \text { IN D ONESIA } & \text { Halaman } 160-164 \\ \text { ISSN: } 2339-2479 & \text { DOI: } 10.14692 / \text { jfi.9.5.160 }\end{array}$

KOMUNIKASI SINGKAT

\title{
Isolasi dan Penapisan in Vitro Aktinomiset untuk Mengendalikan Xanthomonas
}

\author{
Actinomycetes Isolation and In Vitro Screening \\ for Xanthomonas Biocontrol
}

\author{
Yuvika, Aswardi Nasution, Abdul Gafur* \\ AAA Fiber R\&D, Riau 28300
}

\begin{abstract}
ABSTRAK
Penyakit hawar daun bakteri yang disebabkan oleh Xanthomonas sp. sering ditemui pada bibit tanaman Acacia crassicarpa dengan gejala yang diawali oleh bintik-bintik kecil pada daun yang dapat berkembang menjadi hawar daun jika faktor lingkungan kondusif bagi perkembangan penyakit. Aktinomiset merupakan mikroorganisme yang menghasilkan senyawa aktif alami berupa enzim dan antibiotik sehingga aktinomiset layak untuk dipertimbangkan sebagai kandidat agens pengendali penyakit tanaman yang disebabkan oleh bakteri. Pada penelitian ini efektivitas aktinomiset yang diisolasi dari sejumlah lokasi yang berbeda terhadap Xanthomonas diuji secara in vitro. Tujuan dari penelitian ini mendapatkan isolat aktinomiset yang efektif terhadap Xanthomonas untuk mengurangi dampak patogen tersebut terhadap kualitas bibit $A$. crassicarpa. Seluruh koleksi aktinomiset diisolasi dari tanah melalui serangkaian prosedur isolasi pengayaan. Aktivitas antibiotik koleksi diuji melalui penapisan antimikrob menggunakan paper disc pada cawan Petri uji. Sebanyak 75 isolat aktinomiset telah berhasil dikumpulkan dan kemudian diuji. Sebanyak 5 isolat menunjukkan aktivitas antimikrob yang baik dan karena itu merupakan kandidat agens pengendali hayati Xanthomonas yang potensial.
\end{abstract}

Kata kunci: Acacia crassicarpa, agens hayati, antibiotik, hawar daun

\begin{abstract}
Nursery disease frequently found on Acacia crassicarpa seedlings is bacterial leaf blight caused by Xanthomonas sp. Disease symptom starts as a small fleck on the leaf which may then develop to leaf strike or leaf blight if the environmental factors are conducive to disease development. Actinomycetes are soil microorganisms that produce biologically active substances such as enzymes and antibiotics. These compounds could inhibit growth of other microorganisms, particularly bacteria. Thus, Actinomycetes are considered as potential candidates of biocontrol agents for plant pathogens. In the current study Actinomycetes isolated from a wide range of localities were screened for their efficacy against Xanthomonas sp. in vitro. The objective of this study was to obtain Actinomycete isolates effective against Xanthomonas, to mitigate impact of the pathogen on quality of $A$. crassicarpa seedlings. All Actinomycete collections were isolated from soil by a chain of enrichment isolation procedures. The antibiotic activities were investigated through antimicrobial screening tests using paper discs on assay plates. Of the 75 Actinomycete isolates originally collected and screened, 5 isolates showed good antimicrobial activities against Xanthomonas and are therefore considered as potential biocontrol agent candidates.
\end{abstract}

Key words: Acacia crassicarpa, antibiotic, biocontrol agent, leaf blight

*Alamat penulis korespondensi: RGE Technology Center, Pangkalan Kerinci, Riau 28300 Tel: 0761-95550 ext.3125, Faks: 0761-95306, Surel: abdul_gafur@aprilasia.com; gafur@uwalumni.com 
Xanthomonas merupakan bakteri Gram negatif yang dapat menyebabkan penyakit hawar daun pada beberapa tanaman, salah satunya bibit tanaman Acacia crassicarpa. Bagian tanaman yang terinfeksi Xanthomonas, khususnya daun, perlahan-lahan akan mengalami kematian jaringan di sekitar titik serangan untuk menghindari penyebaran serangan tersebut ke jaringan lainnya. Hal tersebut termanifestasi pada gejala bercakbercak kecil dan perubahan warna pada daun. Bila kondisi lingkungan kondusif bagi penyakit, bercak akan berkembang menjadi hawar.

Penanganan untuk mengurangi risiko penyakit hawar daun pada bibit $A$. crassicarpa telah dilakukan dengan banyak cara (Tjahjono et al. 2010), namun pengendalian penyakit menggunakan bahan kimiawi cepat atau lambat dapat menimbulkan masalah ketahanan terhadap patogen dan mengganggu keseimbangan alam. Peningkatan kepedulian terhadap sumber daya alam mengarah pada pemanfaatan agens pengendali hayati. Penggunaan agens pengendali hayati memberi dampak secara perlahan, namun dapat bertahan cukup lama, relatif hemat, dan tidak membahayakan lingkungan (Bafti et al. 2005).

Aktinomiset merupakan mikroorganisme yang telah dikenal dapat dimanfaatkan sebagai agens pengendali hayati dan juga mampu menghambat pertumbuhan mikroorganisme penyebab penyakit pada tanaman (Baniasadi et al. 2009). Kemampuan tersebut didukung oleh karakter alami aktinomiset yang dapat menghasilkan berbagai jenis senyawa metabolit sekunder dan senyawa aktif alami yang bernilai jual tinggi seperti enzim dan antibiotik. Sebagian besar aktinomiset hidup sebagai saprob di dalam tanah, sebagian lagi menempati ekosistem darat lainnya dan perairan.

Dalam penelitian yang telah dilakukan sebelumnya terhadap aktinomiset yang didapat dari beberapa daerah pantai, isolat tersebut mampu menghambat biakan bakteri Escherichia coli, Staphylococcus aureus, Bacillus subtilis, Pseudomonas aeruginosa, dan Stenotrophomonas maltophilia (Ceylan et al. 2008). Selain itu, dalam penelitian lain aktivitas antimikrob aktinomiset tanah diteliti terhadap bakteri Staphylococcus aureus (Ambarwati dan Gama 2009), Klebsiella pneumoniae, Micrococcus luteus, Mycobacterium phlei (Singh et al. 2006), Sclerotium rolfsii (Widyanti dan Giyanto 2013). Oleh karena itu, penggunaan aktinomiset layak dipertimbangkan sebagai kandidat untuk menangani penyakit tanaman, khususnya yang disebabkan oleh bakteri. Tujuan penelitian ialah mengisolasi aktinomiset dari sampel tanah dan melakukan penapisan in vitro isolat yang efektif terhadap bakteri Xanthomonas untuk mengurangi penyakit pada bibit $A$. crassicarpa.

Pengambilan sampel tanah dilakukan di beberapa area hutan tanaman industri di wilayah Riau sebanyak 100 g. Sampel tanah yang diperoleh dikeringanginkan selama kurang lebih 7 hari kemudian dihaluskan. Sebanyak $1 \mathrm{~g}$ sampel tanah kering yang sudah halus dimasukkan ke dalam $100 \mathrm{~mL}$ larutan $\mathrm{NaCl}$ 0.8\%. Campuran kemudian dipanaskan dalam pemanas air pada suhu $55^{\circ} \mathrm{C}$ selama 30 menit, kemudian diinkubasi di atas pengocok pada kecepatan $180 \mathrm{rpm}$ suhu $28^{\circ} \mathrm{C}$ selama 30 menit. Setelah inkubasi selesai dilakukan pengenceran sampai $10^{-4}$ dan diambil sebanyak $1 \mathrm{~mL}$ untuk diinokulasi pada medium casein glycerol agar (CGA) dengan metode cawan tuang. Biakan aktinomiset yang tampak dari hasil isolasi tersebut sampai 2 minggu inkubasi dimurnikan pada medium CGA baru.

Biakan Xanthomonas uji diperoleh dari daun bibit tanaman $A$. crassicarpa yang terserang penyakit bercak daun. Daun diambil dan dibersihkan kemudian dicacah dan dimasukkan ke dalam air steril kemudian diaduk dengan vorteks selama beberapa menit pada kecepatan $1500 \mathrm{rpm}$. Inokulan diambil menggunakan jarum ose untuk diinokulasi dengan cara digores pada medium nutrient agar (NA). Setelah inkubasi 4-5 hari koloni Xanthomonas akan tampak berwarna kuning.

Setiap isolat aktinomiset diuji terhadap biakan Xanthomonas. Isolat aktinomiset murni dibiakkan pada medium casein glycerol cair dan diinkubasi pada pengocok selama 7 hari dengan kecepatan $180 \mathrm{rpm}$ dan suhu $28^{\circ} \mathrm{C}$. 
Selanjutnya, $10 \mathrm{~mL}$ biakan aktinomiset disentrifugasi dengan kecepatan $400 \mathrm{rpm}$ selama 5 menit pada suhu ruang untuk mendapatkan supernatan yang mengandung senyawa aktif. Supernatan hasil sentrifugasi dipindahkan untuk merendam cakram kertas steril dengan diameter $6 \mathrm{~mm}$ selama beberapa saat. Cakram kertas diletakkan di empat titik pada permukaan biakan baru bakteri Xanthomonas yang disebar merata pada medium NA. Inkubasi dilakukan selama 14 hari pada suhu ruang. Pengamatan aktivitas antibiotik dilakukan pada hari ke-3, 8, dan 14 inkubasi dan hasil pengukuran zona hambat dicatat.

Isolat aktinomiset murni diperoleh dengan memisahkan koloni melalui pengamatan secara visual terhadap hasil pencawanan yang telah diinkubasi. Aktinomiset termasuk ke dalam kelompok bakteri Gram positif yang memiliki filamen, dapat membentuk miselium, dan sebagian besar memiliki spora. Pada penelitian ini diperoleh 75 isolat aktinomiset murni. Isolat tersebut tampak melekat kuat mencengkeram medium agar-agar, membentuk miselium dalam pertumbuhannya dan sebagian membentuk spora.

Sebanyak 75 isolat aktinomiset telah diisolasi dari berbagai sampel tanah basah dari lokasi dan dengan karakter yang berbeda. Pengujian aktivitas antimikrob terhadap Xanthomonas dilakukan pada seluruh isolat aktinomiset yang berhasil diisolasi. Peubah digunakan untuk menentukan aktivitas antimikrob ialah terbentuknya zona hambat. Lima isolat aktinomiset menunjukkan adanya zona hambat yang terbentuk dengan tahapan berbeda.

Menurut Watve et al. (2001), sebagian besar jenis antibiotik yang telah ditemukan didapat dari genus Streptomyces. Streptomyces termasuk dalam kelompok bakteri berfilamen aktinomiset, banyak ditemukan di tanah dan memiliki karakter aroma tanah. Isolat aktinomiset yang didapat pada umumnya diperoleh dari lapisan atas tanah yang biasanya mengandung banyak humus. Errakhi et al. (2009) mengisolasi aktinomiset dari tanah yang diambil sampai kedalaman
$10 \mathrm{~cm}$ setelah menghilangkan sekitar $3 \mathrm{~cm}$ bagian permukaan tanah. Pengambilan sampel tanah dengan mengikuti metode ini diasumsikan mendapatkan tanah yang menjadi tempat hidup genus Streptomyces yang diketahui memiliki aktivitas antibiotik.

Senyawa aktif yang dihasilkan oleh aktinomiset dapat memiliki mekanisme yang berbeda-beda dalam menghambat pertumbuhan isolat Xanthomonas. Lima aktinomiset yang diperoleh menunjukkan aktivitas antimikrob yang paling baik. Hal ini menunjukkan bahwa kelima isolat aktinomiset tersebut mampu menghasilkan senyawa antimikrob yang menghambat pertumbuhan bakteri Xanthomonas. Mekanisme aksi senyawa antibiotik terhadap target telah diketahui dan dapat dikelompokkan bergantung pada interaksi senyawa antibiotik dengan target yang berupa fungsi-fungsi yang penting pada sel. Interaksi inilah yang menjadi kunci penghambatan pertumbuhan bakteri. Di dalam sel, proses ini dimulai dengan interaksi antara molekul antibiotik dan target spesifik yang akan mengakibatkan perubahan molekul, biokimia, dan struktural. Proses yang menjadi target dalam mekanisme aksi senyawa antibiotik ialah replikasi DNA, sintesis RNA, sintesis dinding sel, dan sintesis protein (Lima-Procopio 2012). Aktivitas antimikrob dari hasil uji kelima isolat dalam penelitian ini diasumsikan dapat dijelaskan karena mekanisme aksi senyawa antibiotik yang dihasilkan.

Zona hambat dari kelima isolat yang diuji pada penelitian ini ternyata menunjukkan tahapan proses pembentukan yang berbeda. Isolat STA 028, STA 046, dan STA 087 memiliki pola pembentukan zona hambat yang cenderung meningkat pada setiap pengamatan, sedangkan isolat STA 077 dan STA 080 memiliki pola pembentukan zona hambat yang cenderung konstan sejak pengukuran pertama (3 hari) hingga terakhir (14 hari) (Gambar 1). Hal ini kemungkinan terjadi karena perbedaan mekanisme penghambatan dari senyawa aktif yang juga berbeda yang dihasilkan oleh masing-masing isolat aktinomiset tersebut seperti dijelaskan oleh Lima-Procopio (2012). 


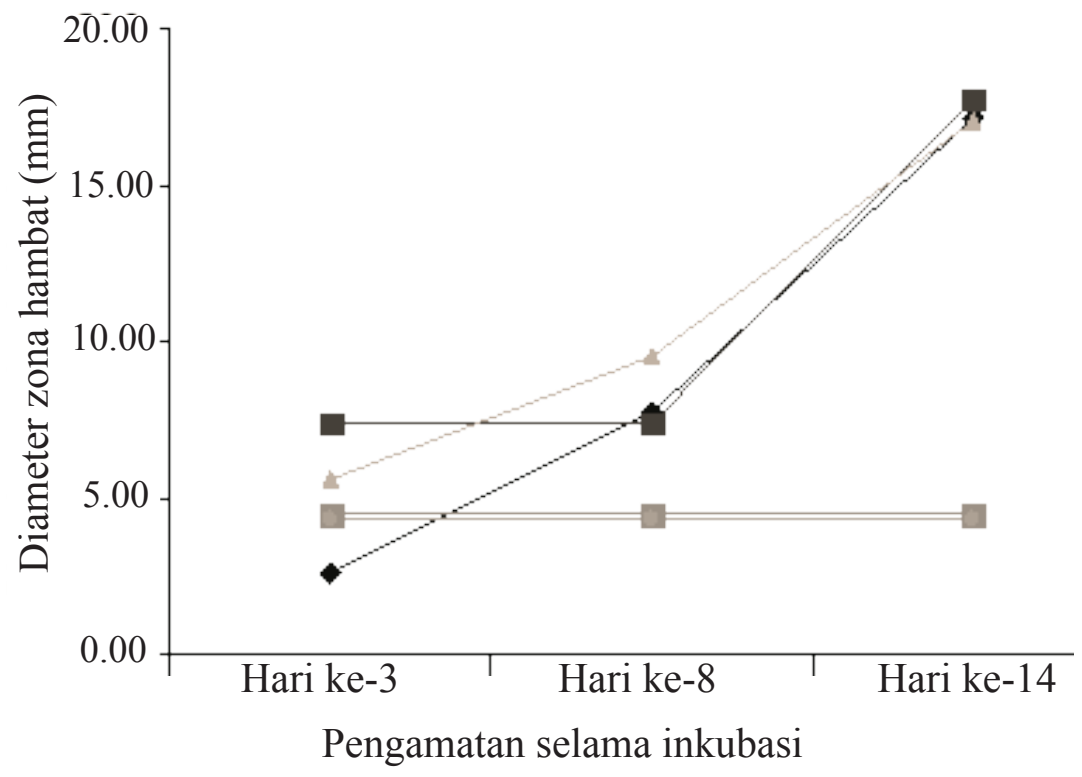

Gambar 1 Tahapan proses pembentukan zona hambat lima isolat aktinomiset selama 14 hari

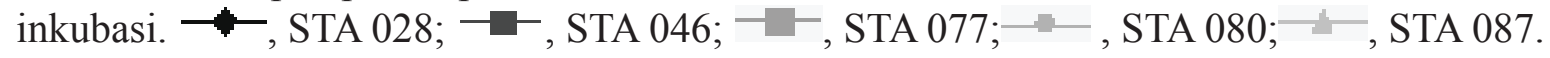

Pengelompokan aktivitas penghambatan isolat aktinomiset pada pertumbuhan bakteri uji dengan diameter 5-9 $\mathrm{mm}$ termasuk katagori lemah, 10-19 mm termasuk katagori sedang, dan $\geq 20 \mathrm{~mm}$ termasuk katagori kuat (Lee dan Hwang 2002). Diameter zona hambat yang diukur tidak termasuk diameter cakram kertas yang digunakan dalam percobaan. Hasil uji aktivitas antimikrob yang dilakukan pada percobaan ini menunjukkan bahwa isolat STA 028, STA 046, dan STA 087 memiliki daya hambat dalam kategori sedang; sedangkan aktivitas isolat lainnya belum dapat dikategorikan sesuai pengelompokan Lee dan Hwang (2002) karena ukuran diameter zona hambat yang dibentuk di bawah ambang batas kategori lemah.

Dalam Jiang dan $\mathrm{Xu}$ (1990) ditulis bahwa kelompok genus Streptomyces banyak ditemukan di tanah yang lebih kering dan tandus. Oleh karena itu, pengambilan sampel tanah selain memperhatikan lapisan atas (top soil) juga mengutamakan tanah yang kering karena banyak menyimpan spora aktinomiset. Sampel tanah yang sesuai dengan karakter tempat hidup aktinomiset diasumsikan memiliki lebih banyak spora aktinomiset yang dapat terisolasi. Semakin banyak isolat aktinomiset yang berhasil diisolasi, semakin besar peluang mendapatkan isolat yang memiliki aktivitas antimikrob yang baik, khususnya terhadap Xanthomonas.

Pada beberapa penelitian, isolat potensial aktinomiset yang diseleksi dari hasil uji in vitro telah diuji secara in vivo terhadap Sclerotium rolfsii pada bibit tanaman gula bit (Errakhi et al. 2009), dan tanaman cabai (Pattanapipitpaisal dan Kamlandharn 2012). Selain itu, isolat aktinomiset juga diuji in vivo terhadap Sclerotinia sclerotiorum pada bibit tanaman bunga matahari (Baniasadi et al. 2009), dan Magnaporthe oryzae pada bibit tanaman padi (Zarandi et al. 2009). Efektivitas in vivo isolat aktinomiset tersebut berbeda-beda bergantung pada jenis isolat yang digunakan, mikroorganisme patogen yang dikendalikan, tanaman inang yang diserang, dan tidak terkecuali faktor eksternal lain yang mempengaruhi secara langsung maupun tidak langsung. Oleh karena itu, isolat aktinomiset yang telah diketahui memiliki aktivitas antimikrob yang baik dari uji in vitro layak untuk diuji secara in vivo. Penapisan in vitro penggunaan aktinomiset sebagai agens pengendali hayati yang dilakukan pada penelitian ini menunjukkan adanya isolat yang potensial dalam mengendalikan bakteri Xanthomonas. 


\section{DAFTAR PUSTAKA}

Ambarwati, Gama TA. 2009. Isolasi aktinomycetes dari tanah sawah sebagai penghasil antibiotik. J Penel Sains Teknol. 10(2):101-111.

Bafti SS, Bonjar GHS, Aghighi S, Biglari S, Farrokhi PR, Aghelizadeh A. 2005. Biological control of Fusarium oxysporum f. sp. melonis, the causal agent of root rot disease of greenhouse cucurbits in Kerman Province of Iran. Am J Biochem Biotechnol. 1(1):22-26. DOI: http://dx. doi.org/10.3844/ajbbsp.2005.22.26.

Baniasadi F, Bonjar GHS, Baghizadeh A, Nik AK, Jorjandi M, Aghighi S, Farokhi PR. 2009. Biological control of Sclerotinia sclerotiorum, causal agent of sunflower head and stem rot disease by use of soil borne actinomycetes isolates. Am J Agri Biol Sci. 4(2):146-151. DOI: http://dx.doi. org/10.3844/ajabssp.2009.146.151.

Ceylan O, Okmen G, Ugur A. 2008. Isolation of soil Streptomyces as source antibiotics active against antibiotic-resistant bacteria. Eur Asian J Biosci. 2:73-82.

Errakhi R, Lebrihi A, Barakate M. 2009. In vitro and in vivo antagonism of actinomycetes isolated from Moroccan rhizosphreical soils against Sclerotium rolfsii: a causal agent of root rot on sugar beet (Beta vulgaris L.). J Appl Microbiol 107:672681. DOI: http://dx.doi.org/10.1111/j. 1365-2672.2009.04232.x.

Jiang CL, Xu LH. 1990. Characteristics of the populations of soil actinomycetes in Yunnan. Actinomycetes. 1(3):67-74.

Lee JY dan Hwang BK. 2002. Diversity of antifungal and actinomycetes in various vegetative soils of Korea. Can J Microbiol. 48(5):407-417. DOI: http://dx.doi.org/ $10.1139 / \mathrm{w} 02-025$.
Lima-Procopio RE, Silva IR, Martins MK, Azevedo JL, Araujo JM. 2012. Antibiotics produced by Streptomyces. The Brazilian Journal of Infectious Diseases. 16(5):466471. DOI: http://dx.doi.org/10.1016/j.bjid. 2012.08.014.

Pattanapipitpaisal P, Kamlandharn R. 2012. Screening of chitinolytic actinomycetes for biological control of Sclerotium rolfsii stem rot disease of chilli. Songklanakarin J Sci Technol 34(4):387-393.

Singh LS, Baruah I, Bora TC. 2006. Actinomycetes of Loktak habitat: isolation and screening for antimicrobial activities. Biotechnology. 5(2):217-221. DOI: http:// dx.doi.org/10.3923/biotech.2006.217.221 .

Tjahjono B, Ernawati NML, Giyanto, Gafur A. 2010. Bacterial leaf blight on Acacia crassicarpa caused by Xanthomonas campestris in Indonesia. Di dalam: Prosiding ISSAAS International Congress; 2010 Nov 14-18; Bali (ID): ISSAAS.

Watve MG, Tickoo R, Jog MM, Bhole BD. 2001. How many antibiotics are produced by the genus Streptomyces?. Arch Microbiol. 176(5):386-390. DOI: http:// dx.doi.org/10.1007/s002030100345.

Widyanti N, Giyanto. 2013. Kemampuan aktinomiset menghambat pertumbuhan Sclerotium rolfsii dan pembiakannya pada medium serbuk gergaji. J Fitopatol Indones. 9(1):7-14. DOI: http://dx.doi. org/10.14692/jfi.9.1.7.

Zarandi ME, Bonjar GHS, Dehkaei FP, Moosavi SAA, Farokhi PR, dan Aghighi S. 2009. Biological control of rice blast (Magnaporthe oryzae) by use of Streptomyces sindeneusis isolate 263 in greenhouse. Amer J Appl Sci 6(1):194199. DOI: http://dx.doi.org/10.3844/ ajassp.2009.194.199. 